UDK 94:314.117.13/.15(497.115)"19”

$323.1(=163.41:=18)(497.115)$

doi: $10.5937 /$ bastina30-25562

Originalni naučni rad

Dragan Lj. TANČI Ć

Institute of Serbian Culture Pristina, Leposavić

Dalibor M. ELEZOVIĆ**

Faculty of Philosophy Kosovska Mitrovica

\title{
POLITICAL PROCESSES IN KOSOVO AND METOHIJA IN A COMPARATIVE-HISTORICAL PERSPECTIVE
}

Abstract: The paper discusses the issue of political processes in Kosovo and Metohija in a comparative historical perspective. We consider the historical vertical line of processes that followed the political situation of the Serbian people in this area, as well as political processes and events that have marked the contemporary crisis in Kosovo.

Key words: Kosovo and Metohija, Serbia, history, political processes, Serbs, Albanians

The area of today's Kosovo and Metohija is one of the fundamental factors of Serbian state and national identity. It is a territory that was the center of Serbian statehood and culture from the twelfth century to the mid-fifteenth century. From the mid-fifteenth century to the early twentieth century, i.e. the Balkan wars, Kosovo was under the rule of Turkey. One of the political impacts of Turkish invasion policy, which can be observed and identified in this region in an indisputable manner, refers to the process of changing the ethnic structure of the population, so that the Serbs as a people have become the absolute minority from the absolute majority, which is evidenced by the following data: a) according to the Turkish census dated 1455 (Мацура, 2001) in the area of Kosovo, there were 98\% of the Serbs and 1\% of the Albanians; b) according to the Austrian data, there were 64\% of the Serbs and 32\% of the Albanians; c) according to the census in the Kingdom of Serbs, Croats, and Slovenes in 1921, there were $26 \%$ of the Serbs and $66 \%$ of the Albanians and, according to the 1931 census, there were $32.6 \%$ of the Serbs, and $60.1 \%$ of the Albanians. From the above statistics, we can see a pattern implying that the Turkish occupation and genocidal policy against the Serbian people up to the Balkan wars brought demographic changes in the direction of the decrease in the number of the Serb

\footnotetext{
* Associate Professor, dragan_tancic@yahoo.com

** Associate Professor, dalibor.elezovic@pr.ac.rs
} 
population, which continued through the first half of the 21 st century in changed circumstances, as can be seen in the tables and charts that follow:

Table 1. Population in Kosovo and Metohija 1455-1931

\begin{tabular}{|c|c|c|}
\hline Census year & Albanians & Serbs \\
\hline 1455 & $1 \%$ & $98 \%$ \\
\hline 1871 & $32 \%$ & $64 \%$ \\
\hline 1921 & $66 \%$ & $26 \%$ \\
\hline 1931 & $60.1 \%$ & $32.6 \%$ \\
\hline
\end{tabular}

Chart showing the ratio of the number of Serbs and Albanians from 1948 to 2006 in Kosovo and Metohija, according to the statistics of the Yugoslavian Federal Statistical Office.

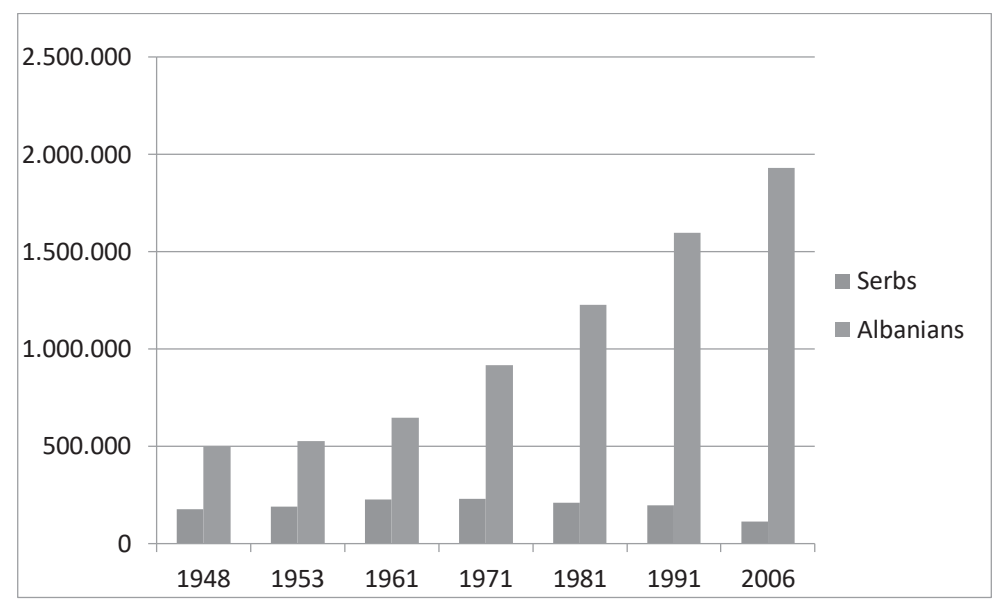

Table 2. Population in Kosovo and Metohija 1948-2006

\begin{tabular}{|c|c|c|c|c|c|c|}
\hline Census year & Total & Albanians & Serbs & Turks & Roma & Others \\
\hline 1948 & 733.034 & 498.244 & 176.718 & 1.320 & 11.230 & 45.522 \\
\hline & 100 & $68,0 \%$ & $24,1 \%$ & $0,2 \%$ & $1,5 \%$ & $6,2 \%$ \\
\hline 1953 & 815.908 & 524.562 & 189.869 & 34.590 & 11.904 & 54.983 \\
\hline & 100 & $64,3 \%$ & $23,3 \%$ & $4,2 \%$ & $1,5 \%$ & $6,7 \%$ \\
\hline 1961 & 963.988 & 646.605 & 227.016 & 25.764 & 3.202 & 61.401 \\
\hline & 100 & $67,1 \%$ & $23,5 \%$ & $2,7 \%$ & $0,3 \%$ & $6,4 \%$ \\
\hline 1971 & 1.243 .693 & 916.168 & 228.264 & 12.244 & 14.593 & 72.424 \\
\hline & 100 & $73,7 \%$ & $18,4 \%$ & $1,0 \%$ & $1,2 \%$ & $5,8 \%$ \\
\hline 1981 & 1.584 .440 & 1.226 .736 & 209.798 & 12.513 & 34.126 & 101.267 \\
\hline & 100 & $77,4 \%$ & $13,2 \%$ & $0,8 \%$ & $2,2 \%$ & $6,4 \%$ \\
\hline 1991 & 1.956 .196 & 1.596 .072 & 194.190 & 10.445 & 45.754 & 109.744 \\
\hline & 100 & $81,6 \%$ & $9,9 \%$ & $0,5 \%$ & $2,3 \%$ & 5,6 \\
\hline 2006 & 2.100 .000 & 1.932 .000 & 111.300 & 8.400 & 23.512 & 24.788 \\
\hline & 100 & $92 \%$ & $5,3 \%$ & $0,4 \%$ & $1,1 \%$ & $1,2 \%$ \\
\hline
\end{tabular}


Within the Serbian medieval feudal state, Kosovo had a significant position (Šešlija, 2000), and a compact Serbian population lived in this area. Serbian medieval rulers often stayed on the territory of Kosovo. Kosovo and Metohija was an important center of economic activities of medieval Serbia. The most important mining town in Serbia in the Middle Ages was Novo Brdo, mentioned in 1326 , which was the center of trade with the Balkan countries. Lead was mined there, especially silver mixed with gold, called "glama" or "glama silver." In the fourteenth century, money was forged there. The development of the Kosovo area as a center of Serbian spirituality in the Middle Ages can be seen through a large concentration of Serbian churches and monasteries in this territory (over two hundred preserved or demolished temples). Large dynastic mausoleums and monastic communities are also in Kosovo: The Patriarchate of Pec, Banjac, Gradac, Gracanica, Decani, Holy Archangels and a number of other, smaller, important monasteries. During the Nemanjic dynasty, a large number of (religious and secular) structures was built in Kosovo. The Patriarchate of Pec was built in stages. The first church, the Holy Apostles, was probably built by an abbot of Zica, Arsenije, who was a Serbian Archbishop later, in the third decade of the thirteenth century in the community of the Zica manor. In the fourteenth century, other temples were built: to the northern side of the Holy Apostles, the Church of St. Demetrius (Nikodim, between 1321 and 1324), and to the southern side, the Church of the Virgin Hodegetria with chapels of John the Baptist and Serbian St. Arsenije (Danilo II 1324 to 1337). Somewhat later, yet before 1337, a shared porch and a small temple of St. Nicholas were built against the southern wall (Šešlija, 2000). The most significant monument of Serbian construction industry in Kosovo was the Decani Monastery, which was built by Stefan Uros II (Decanski, 1321 to 1331), in the period from 1327 to 1335, when it was finished by King Stefan Dusan. It is a temple of the Pantocrator (Almighty), near the village of Decani, near the town of Рес. (Батаковић, 1991; Батаковић, 1998; Богдановић, 1985; Зиројевић, 1984; Микеуснић, 2002). Numerous monuments of medieval feudal Kosovo are a sufficient argument to prove that the territory of Kosovo in the Serbian state was an important area where major events occurred, both in the sphere of politics and culture (UNESCO). The occupation of Smederevo in 1459 implied the downfall of Serbia, when the Serbian Despotate fell under the Ottoman rule, in which it remained until the First Serbian Uprising - in 1804. The fall of Smederevo was a concern for Western Europe both military and politically, since a real danger that threatened Christianity by the Turks could be felt only then. Only then did everyone realize what a serious threat it was to Christians in general, to Europe. The structure of the population in the coming centuries was changed by the migrations in 1690 and 1740, by the Islamization and assimilation of Serbian population (Milivojević, 2002: 281-288; Словић, 2010: 278-290; Стојанчевић, 1994; Терзић, 2012; Урошевић, 1965). 
After the First Balkan War, Serbia was territorially enlarged, gaining a common border with Montenegro, which provided free export to Thessaloniki and expanded its economic potentials, while its foreign policy position and reputation in the international community was substantially increased. On the other hand, the negative effects and consequences for Serbia were: the newly formed Albanian state and the fact that it became an instrument of the Austro-Hungarian politics and one of the strongholds for the penetration to the east, towards Thessaloniki. Significantly changed, the ethnic structure of the population of the Old Serbia and Western Macedonia and problems due to frequent raids of Albanian tribes in the valleys of Morava and Vardar (initiated by Vienna) substantially complicated the relations among the members of the Balkan League. The Treaty of Bucharest on 10 August 1913 made the final division of the territory gained in the First Balkan War: Serbia received Vardar Macedonia, Kosovo and a part of Metohija, so that it was an increase of $39,000 \mathrm{~km}^{2}$ and around $1,290,000$ inhabitants. The Second Balkan War shattered the Balkan League, thus strengthening the influence of the imperialist powers in the Balkan states. By the annexation of Kosovo and Metohija to the Kingdom of Serbia and Montenegro, the Albanians found themselves in the Serbian states in accordance with the provisions of the Serbian Constitution of 1903 and the provisions of the Montenegrin Constitution of 1905 , contrary to the intentions that were manifested in the period from 1878-1912 to establish "Greater Albania," a part of which Kosovo and Metohija would be, among other Albanian areas (Nedeljković \& Jović, 1999: 241-251). A large part of the Albanian population saw the arrival of Serbian and Montenegrin Armed Forces as occupation rather than as liberation from Turkish rule. During World War I, after the withdrawal of Serbian army in 1915, Kosovo and Metohija was divided into two occupation zones. Metohija entered into the General Administration of "Montenegro," while a smaller part of Kosovo with Kosovska Mitrovica and Vucitrn entered into the General Administration of "Serbia." A large part of Kosovo (Pristina, Prizren, Gnjilane, Urosevac, Orahovac) became part of the Bulgarian Military Inspection area of "Macedonia." The members of the Serbian people suffered the worst in both zones. After the penetration of the Salonika front, in early October of 1918, Serbian and French armies arrived at the area of Kosovo and Metohija, where civil, military and police authorities were established. Until December 1918, the Serbian Army managed to defeat Albanian rebellions with intensive actions and implemented disarmament campaigns. From 1941 to 1945, in Kosovo and Metohija, a regime of Quisling administration of "Greater Albania," which was administrated from Tirana, was established. It was a period of extreme Albanian domination. The Quisling administration had a strong support of the Albanian population. With the dissolution of the Italian protectorate, the so-called, "Greater Albania" continued to function, gaining the only international recognition by Nazi Germany. 
The Albanians showed their loyalty, i.e. commitment to the German ally by forming the 21st SS Division "Skanderbeg" (with 11,000 soldiers) and the Kosovo Regiment - Regimenti Kosova (with 1,000 gendarmes), under German command in the summer of 1943 (Антонијевић, 2004). On the other hand, the command of the partisan movement in Kosovo and Metohija supported the tendency towards the annexation of Kosovo and Metohija to Albania (which could most clearly be seen in the decisions of the Conference of Bujan, held in the village of Bujan, on the Albanian side of the Serbian (Yugoslav) - Albanian border on 31 December 1943 and 1 and 2 January 1944. The conference adopted the Resolution (after the Second session of AVNOJ), in which they pointed out the tendency towards the annexation of Kosovo and Metohija to Shqipnia (Albania), since, as stated in the Resolution, "Kosovo and Metohija is an area that is mostly inhabited by the Shqiptar population, which always wants to be united with Shqipnia..." The decisions of the Conference of Bujan encountered the condemnation of the Central Committee of the CPY (Communist Party of Yugoslavia), which overturned the same. In addition, the efforts to change the name Metohija into Dukagjin (a geographical concept related to the north of Albania) were thwarted. These efforts were particularly significant, since it was expected from the partisan authorities in Kosovo and Metohija to become the future leaders of governments in the region. With the liberation of Kosovo and Metohija from German occupation in autumn of 1944, an open rebellion of ballistic groups occurred. They attacked Urosevac and Gnjilane already in December of the same year. Mobilized Albanians (under the leadership of the partisan officer Saban Poluza) rose in rebellion, refusing to go to the north (the front of Srem), and instead starting an uprising against the Yugoslav authorities in the area of Drenica. On 8 February 1945, Josip Broz made a Decision on The Recognition of State of Belligerency. The rebellion was suppressed in late February, with the involvement of 39 thousand soldiers of the Yugoslav army. At that time, Blagoje Neskovic, one of the leading Serbian communists, said that the Albanians were "frontally against the new order" (Petranović, 1992). Then, the Regional National Assembly of Kosovo and Metohija made the Resolution on the Annexation of Kosovo and Metohija to Federal Serbia in Prizren on 9 July 1945. It pointed out that "the Shqiptar population enjoys real equality and has the possibility to, in close cooperation with the Serbian and Montenegrin population and with the help of democratic Serbia and the entire Democratic Federal Yugoslavia, contribute their forces to their appropriate cultural development and economic and social progress." It also expressed the consent to decisions of the Second Session of AVNOJ and the wish of the entire population residing in this area for this region to be "annexed to federal Serbia as its integral part.” This decision was upheld by the Anti-Fascist Assembly for the National Liberation of Serbia, followed by the Presidency of AVNOJ on 23 July 1945. 
The process of the reconstruction of Serbian (Yugoslav) statehood in Kosovo and Metohija was quite complex (Tančić, 2010: 293-299).

The Constitution of the Federal Republic of Yugoslavia (FNRY) of 31 January 1946 established the existence of two autonomous units within the People's Republic of Serbia, the Autonomous Province of Vojvodina and the Autonomous Region of Kosovo and Metohija, which could be seen from Article 2 of the Constitution of FNRY (Article 2, Item 2: - People's Republic of Serbia has in its composition the Autonomous Province of Vojvodina and the Autonomous Region of Kosovo and Metohija) (Hrabak, 1996: 151-160), wherein it was determined that the autonomous rights and obligations of the autonomous province of Kosovo and Metohija were exercised by the Constitution of the Republic (Article 103: - The rights and scope of autonomy of the autonomous provinces and the autonomous regions are determined by the Constitution of the Republic), and the Statutes of the province and the region would be adopted in accordance with the Federal Constitution and the Constitution of the Republic (Article 104: - The Statute of the autonomous province and the autonomous region shall be adopted in accordance with the FNRY Constitution and the Constitution of the Republic, the highest authority of the state authority of the autonomous province or autonomous region, and it shall be approved by the National Assembly of the Republic). The first Constitution of the People's Republic of Serbia was adopted on 17 January 1947 by the Constituent Assembly and was applied until 13 January 1953, until the adoption of the Constitutional Act on the Fundamentals of Social and Political Organization and the Federal Government, which was in accordance with the Federal Constitution, i.e. the FNRY Constitution of 1946. The constitutional amendments VII- XIX (a total of 13 amendments), which were adopted on 26 December 1968, carried out a thorough revision of the Constitution of 1963, i.e. the fourth group of amendments that referred to the constitutional and the legal status of the autonomous province. Namely, Amendment VII referred to the autonomous provinces as the socialist provinces, not "social and political communities within the republic." By Amendment XVIII of December 1968, the autonomous provinces were identified as a constitutive element of the Federation and as an integral part of the Socialist Republic of Serbia (Hrabak, 1996: 160-166). The said amendments of the constitutional revision then began the process of weakening the federal state and federalism, and, on the other hand, the strengthening of the republics and the autonomous provinces, which, in the later constitutional development had far-reaching negative effects and consequences for SFR Yugoslavia, and the Republic of Serbia, as well. The third group of the amendments of 30 June 1971, (Tančić, 2010: 300-309).

A total of 23 amendments (XX-XLII), comprehensive radical changes of the revision of the Constitution of 1963 were made. By these constitutional 
amendments, the autonomous provinces became federal units with significant factors of statehood, and the relations between the federation-republic and the provinces were changed in the field of credit and monetary policy, enforcement of federal laws, etc. By the 1974 Constitution, Kosovo gained the factual status of a federal unit of SFR Yugoslavia, although it was formally still part of SR Serbia. Kosovo lost the status of de facto federal unit by the Constitution of Serbia of 1990, and since then, it has been called the Autonomous Province of Kosovo and Metohija within Serbia. Part of Albanians unilaterally declared independence in 1990, but it was not recognized by any state except for Albania. In 1996, the Albanian terrorist organization, KLA, began attacks on police and other state authorities of Serbia. This turned into a serious conflict in 1998, when terrorist attacks on the regular security forces expanded to the entire Province. After diplomatic pressures by the US and the EU against Yugoslavia to withdraw military and police forces from the Province and enable the Albanians a greater level of autonomy, NATO openly threatened to bomb. In October 1998, Yugoslav President Slobodan Milosevic and US envoy Richard Holbrooke reached an agreement on the deployment of the observation mission OSCE in Kosovo and Metohija and the withdrawal of part of the military and police forces, which temporarily eliminated the danger of NATO bombing. Despite this, the KLA continued their terrorist attacks (Elezović, 2009: 352-357). After the Recak case in January 1999, there were new threats of bombing by the United States, NATO and other countries. In February 1999, there was a peace conference known as the Rambouillet negotiations, which was attended by representatives of the FRY, Kosovo Albanians, EU, USA and Russia. After three weeks of negotiations, no agreement was reached. For the USA and the EU, this was the last attempt to resolve the Kosovo crisis peacefully, and they sent an open ultimatum to FRY authorities that NATO bombing would occur if they did not accept the proposal of the Rambouillet agreement, which prescribed the presence of military NATO forces in the country and the autonomy of Kosovo and Metohija, bordering on independence (a referendum on independence was scheduled three years from then). After the FRY dismissed this, NATO bombing ensued on $24 \mathrm{March}$, in contravention of international law (without the consent of the UN Security Council). The bombing ended after 78 days with the Kumanovo Agreement and the Resolution 1244 of the Security Council. After the implementation of this agreement, more than 200,000 Serbs and other non-Albanians were exiled from Kosovo and Metohija. After the conflict ended, the KLA continued to commit atrocities against Serbian civilians. Kosovo and Metohija came under the UN administration (Анчев, 2016: 20-24).

According to Resolution 1244, Kosovo and Metohija is an integral part of Serbia, but, massive ethnic cleansing of Serbs in the territory of Kosovo and 
Metohija, known as the March Pogrom, happened under the control of UNMIK on 17 and 18 March 2004. Serbian authorities and representatives of the provincial Albanians opened negotiations on the status of the territory in Vienna in 2006. Finnish diplomat Marti Ahtisaari proposed a plan for a sustainable solution of the status - the independence of the province under the supervision of the international community. His plan was not accepted at the UN General Assembly thanks to Russia, which initiated sending a Mission to determine the factual situation in Kosovo and Metohija and the degree of implementation of Resolution 1244. The Mission report was insufficient, so that, starting in August 2007, new negotiations were opened on the issue at the request of Serbia, this time under the leadership of the EU, the US and Russia (Гускова, 2012: 239260). The first two rounds were on the side of the Albanians, who, in the talks, insisted on independence as the only solution. Soon, there followed the adoption of the Declaration of Independence of Kosovo. The Provisional Assembly of Kosovo and Metohija held a session on 17 February 2008, during which the declaration was adopted, and it was signed after the adoption by interim President of Kosovo Fatmir Sejdiu, interim provincial Prime Minister Hashim Thaci and President of the Interim Assembly Jakup Krasniqi and then by all the members of the Assembly of Kosovo. The entire event was covered by 3,000 accredited journalists, pointing to the open support of the US and the West for the Albanians in Kosovo and Metohija and the separation of Kosovo and Metohija from the Republic of Serbia, which is contrary to the provisions of Resolution 1244, the Serbian Constitution and the provisions of international law. It is obvious that the authorities of the Provisional Self-Government in Kosovo and Metohija were not able to adopt the said declaration without the support of the US, EU and other countries (Гускова, 2014).

In its decision of 14 February 2008, the Government of the Republic of Serbia overturned the unilaterally proclaimed independence of Kosovo and Metohija, which highlighted a clear commitment that Kosovo is an inalienable part of a unique and indivisible constitutional and state legal order of Serbia (Анчев, 2016: 26; Анчев, 2002). The declaration of independence of Kosovo and Metohija, an integral part of the territory of the Republic of Serbia as a sovereign state, without its consent, was an illegal act that was in contradiction with the UN Charter and the Helsinki Final Act (OSCE), in contradiction with the Constitution of the Republic of Serbia and international documents - The AhtisaariChernomyrdin Agreement, which was adopted at the session of the National Assembly of Serbia and the FRY Government on 3 June 1999, Resolution 1244 of the UN Security Council (1999) and the Military Technical Agreement (1999). The support of individual UN members for the Albanians from Kosovo and Metohija and their recognition of the unilaterally declared independence is a precedent in international law, with which, some UN members acknowledged 
their recognition of the right to secession of part of the territory of a UN member without its consent. Thus, the right to self-determination and secession of members of an ethnic minority, apart from many other national minorities in Serbia, was recognized.

It is undisputed that the unilateral proclamation of independence of the province of Kosovo and Metohija is a threat to the stability of Serbia, the region and beyond (Гускова, 2012: 976-980). This is confirmed in case of Catalonia in Spain. It is obvious that, in a part of the international community, there is one international law when it comes to Kosovo and Metohija, but when it comes to Catalonia, there is another international law. This view was taken by the administration in Brussels, which can be seen from the statement of the spokesman of the European Commission, Margaritis Schinas, according to whom "the cases of Kosovo and Catalonia are incomparable," the recognition of Kosovo is a "very specific context" and such a position was adopted by the European Council on the basis of the UN declarations and various resolutions of the UN and the international community. The European Union believes that the issue of Catalonia is an internal issue of Spain, that the referendum on the independence of Catalonia cannot be legal, but it is forgotten that the EU Council of Ministers has adopted a political stance that Kosovo is a "unique case" that cannot serve as a precedent in international relations, that secession was allowed without a referendum in case of Kosovo and Metohija. On the other hand, one should bear in mind the opinion of a judge of the International Court of Justice, Abdul Koroma, who has unequivocally taken a stand that the declaration of independence of Kosovo and Metohija is illegal and void, which is also a stand of some other judges who have the same point of view.

By studying various political processes related to Serbia in international relations, starting from the Middle Ages, and concluding with the second decade of the twenty-first century, we can draw several conclusions:

1. For Serbia, as a specific state and political entity and a subject of international relations (from the Nemanjic Dynasty to the beginning of the twenty-first century), Kosovo and Metohija represented and represents one of the fundamental factors of Serbian state, national and cultural identity.

2. The penetration of Turkey in the Balkans and the fall of Serbian medieval state compromised Christianity in the entire Europe. The relations of Turkey and the majority Muslim Albanians towards the Serbian people in Kosovo and Metohija were extremely negative; the Serbs in this area were peasants, living in a feudal system until the Balkan wars in the early twentieth century.

3. In socialist Yugoslavia in 1946, the constitutional changes reinforced the status of Kosovo and Metohija as an autonomous unit, and by the constitution of 1974, it gained the status of a federal unit of SFR Yugoslavia, although it was still part of SR Serbia formally. 
4. The US and NATO aggression against the Federal Republic of Yugoslavia violated the basic principles and foundations of international law, relating to respect for the sovereignty of all states, refraining from threats or use of force, inviolability of borders and territorial integrity, the peaceful settlement of international disputes, non-interference in internal questions of the states, as well as the overall implications of the constitutional status of Serbia and Kosovo and Metohija within Serbia on the basis of the adopted documents Ahtisaari-Chernomyrdin Agreement, the Security Council Resolution 1244, the Military Technical Agreement between the security forces (KFOR) and the Government of the FRY and the Republic of Serbia.

5. From the arrival of Turkey at the territory of Serbian medieval state all the way to the contemporary political processes, we can see that there has been a tendency to destroy the Serbian people and the Serbian state, both its statehood, and Serbian cultural heritage and identity. This can especially be seen in the case of Kosovo and Metohija within Serbia starting from 1999 all the way to its recognition as an independent state and beyond.

\section{REFERENCES}

Антонијевић (2004): НенаА Антонијевић. Албански злочини наg Србима на Косову и Ме-

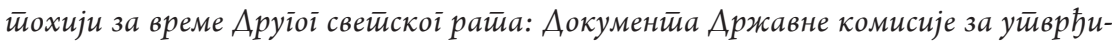
вање злочина окуйайора и њихових йомаїача. Крагујевац-БеограА: Музеј жртава геноцида.

Анчев (2016): Стефан Анчев. „Косово Аанас-национална бол, наметнут избор, упориште агресора или повод за дестабилизацију“, Век срӣске Голі̄отее: (1915-2015) Књ. 3, Арушіивене науке. К. Митровица: Фикозофски факултет, 2016, 19-28.

Анчев (2002): Стефан Анчев. Роgината ми в NATO?: БЂлгарийо, ... ти си честна страна!: публицистични материали за съвременната ни действителност, писани през периoga 1990-1992 и 1999-2001 година. В. ТЪрново: Faber.

Батаковић (1991): Аушан Батаковић. Косово и Мейохија у срйско-арбанашким о оносима:

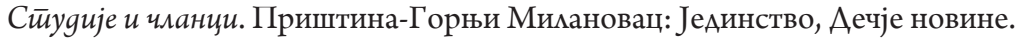

Батаковић (1998): Аушан Батаковић. Косово и Метиохија: Исӣорија и ияеолоїија. БеограА: Хришћанска мисао.

БогАановић (1985): Аимитрије БогАановић. Књиіа о Косову. БеограА: Српска академија наука и уметности.

Vasić (2004): Nenad Vasić. „Etničke zajednice i etnički konflikti na Kosovu i Metohiji“. Baština, (17), 173-197.

Гускова (2012): Јемена Гускова. „Балканска криза: последице и поуке за словенски свет“,

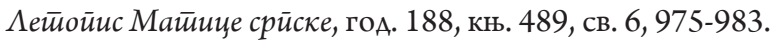

Гускова (2014): Јемена Гускова. Косово и Мет̄охија: рай и услови мира. Косовска Митровица: Филозофски факултет.

Гускова (2012): Јемена Гускова. „Переговорнии процес в Косово и Метохии 2006-2007 и Росиа“, Косово и Мет̄охија 1912-2012. Косовска Митровица: Филозофски факултет, 239-261. 
Елезовић (2010): Аалибор Елезовић. „Амитровица и околина почетком 17. века: историјски пресек на основу османског пописа из 1604. године“ у М. Атмагић (уреА.)

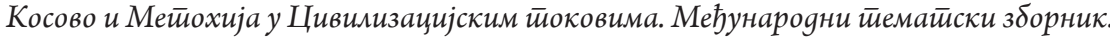
Књиіа 3 Истиорија, Иситорија умейностии, К. Митровица: Филозофски факултет.

Elezović (2009): Zvezdana Elezović. „Skulpturom protiv '(Ne)milosrdnog anđela'“. Baština, (26), 351-360.

Zirojević (2003): Olga Zirojević. Islamizacija na južnoslovenskom prostoru: dvoverje. Beograd. Зиројевић (1984): Олга Зиројевић. Цркве и манасиичри на йоgручју Пећке ӣайријариије gо 1683. іолине. БеограА: Историјски институт.

Мацура (2001): Милош Мацура. Насеља и сииановнишиево Обласиии Бранковића 1455. їодине, Аемоірафски зборник, Књиіа VI. БеограА: САНУ.

Мияеуснић (2002): Слободан Мияеуснић. Манастиири Србије: велика илустирована енциклоüeguja, I и II. БеограА: Православна реч.

Milivojević (2002): Snežana Milivojević. „Etnička struktura i etničke promene na Kosovu u delu Atanasija Uroševića“. Baština, (14), 117-122.

Milivojević (2002): Snežana Milivojević. „Etnička smena stanovništva na Kosovu i Metohiji“. Baština, (14), 281-290.

Mirković (2013): Ena Mirković. „Referat o političkom stanju u Srbiji, Vojvodini i Kosovu i Metohiji“. Baština, (35), 229-248.

Nedeljković \& Jović (1999): Slaviša Nedeljković. „Istorijsko-geografski pogled na demografske karakteristike Kosova i Metohije krajem XIX i početkom XX veka“. Baština, (9-10), 241-251.

Petranović (1992): Branko Petranović. Srbija u drugom svetskom ratu 1939-1945. Beograd: Vinc. Радовановић (2008): Милован Раgовановић. Косово и Мейохија: Анйройоїеоірафске, истиоријскоїеоірафске, демоірафске и іеойолитичке основе. БеограА: Службени гласник.

Slović (2010): Srđan Slović. „Kosovo i Metohija od 1900. godine do početka Prvog Svetskog rata“. Baština, (28), 277-292.

Službeni list (1971): Službeni list. Socijalističke Federativne Republike Jugoslavije, godina XXVII, broj 29, Beograd, četvrtak, 8. jul 1971.

Стојанчевић (1994): Владимир Стојанчевић. Косово и Метиохија у срйско-арбанашким оgносима у XIX веку (1804-1878). БеограА: Српска академија наука и уметности.

Tančić (2010): Dragan Tančić. „Položaj Kosova i Metohije od Balkanskih ratova do 1945. godine“. Baština, (28), 293-311.

Терзић (2012): Славенко Терзић. Стиара Србија: (ХІХ-ХХ век): gрама јеgне циивилизачије: Рашка, Косово и Мейохија, Скойско-йетиовска области. Нови СаА: Православна реч; БеограА: Историјски институт.

Урошевић (1965): Атанасије Урошевић. Косово, Насеља и йорекло стиановнишйва, књ. 39. БеограА: САНУ.

Ustav FNRJ (1946): “Ustav FNRJ. od 31.01.1946. godine”, u: Ustavi od 1921. do 2003., elektronsko izdanje, Službeni list SCG. Beograd.

Hrabak (1996): Bogumil Hrabak. „Kosovo i Metohija prema Prvom srpskom ustanku“. Baština, (7), 151-168.

Šešlija (2000): Žarko Šešlija. Kosovo i Metohija u političkoj istoriji Srbije od 1912-1999 godine. Beograd.

http://whc.unesco.org/en/list/724 [accessed, 24.10.2019]. 


\section{Араган ऽ. ТАНЧИТ \\ Аалибор М. ЕАЕЗОВИЋ}

\section{ПОАИТИЧКИ ПРОЦЕСИ НА КОСОВУ И МЕТОХИЈИ У КОМПАРАТИВНО-ИСТОРИЈСКОЈ ПЕРСПЕКТИВИ}

\section{РеЗиме}

У раду аутори разматрају питање политичких процеса на Косову и Метохији у компаративно-историјској перспективи. Анализира се историјска вертикала процеса који су обележили историју српског народа на овом простору, као и политички процеси и догађаји који су обележили савремену кризу на Косову и Метохији. Реч је о територији, која је бима центар српске Аржавности и културе Ао пада под османлијску власт. ЈеАна оА последица османлијске вцасти који се на неспоран начин може опазити и иАентификовати, оАноси се на процес измене етничке структуре становништва, тако Аа су Срби као нароА, оА апсолутне већине постали апсолутна мањина. Таква тенденција се заАржала и током 20. века када је Србија и Косово и Метохија као њен део, била у саставу социјалистичке Југославије. Агресијом НАТО на СРЈ су прекршени основни принципи и темељи међународног права, што је довело до егзодуса српског народа са простора Косова и Метохије. Неспорно је аа јеАнострано проглашење независности покрајине Косово и Метохија 2008. године, преАставьа опасност по стабилност Србије, региона и шире. Истраживање показује да Косово и Метохија преАставља јеАан оА фундаменталних чинилаца српског Аржавног, националног и културног идентитета током дугог историјског трајања.

Кьучне речи: Косово и Метохија, Србија, историја, политички процеси, Срби, А^банци

РаА је предат 22. фебруара 2020. године, а након мишьења рецензената, оАлуком одговорног уредника Башӣине, одобрен за штампу. 